\title{
Computational Assessment of Dose due to Primordial Radionuclides in Soils of Coastal Regions of Kanyakumari District in Tamil Nadu, India
}

\author{
V. Sarojini ${ }^{1}$, T. Chithambarathanu ${ }^{2}$ \\ ${ }^{1}$ Assistant Professor, Lekshmipuram College of Arts and Science, Neyyoor-629802, Tamil Nadu, India \\ ${ }^{2}$ Associate Professor, S.T.Hindu College, Nagercoil- 629001, Tamil Nadu, India
}

\begin{abstract}
The natural radioactivity due to uranium, Thorium and potassium in soil contributes to the radiation dose received by human beings significantly. Gamma ray spectrometric measurements carried out for the natural radioactivity levels due to ${ }^{226} \mathrm{Ra},{ }^{232} \mathrm{Th}$ and ${ }^{40} \mathrm{~K}$ in beach sand samples around the coast of Kanyakumari district were analyzed. For assessing the environmental radiological impact to public it is essential to evaluate the activity levels of these radionuclides. The absorbed dose rate due to natural radionuclides was also calculated and the results are reported in this paper. The total annual effective dose of the study area founds to vary between $1.86 \mathrm{mSv}$ to $2.67 \mathrm{mSv}$. This study provides a baseline data of radioactivity background levels in some Naturally High Background Radiation Areas along the coastal regions of Kanyakumari district and will be useful to assess any changes in the radioactive background levels.
\end{abstract}

Keywords: Natural radioactivity, radionuclides, dose

\section{Introduction}

Terrestrial sources contribute about $84 \%$ of the total radiation from natural sources to which an individual is exposed. It is an accumulated effect arising from a number of materials around us such as rock, soil, water, food and from within human body. It is obvious that people living in areas with large concentrations of radionuclides might be getting more than the average annual dose of radiation. Such areas are in Brazil, Sweeden, France and coastal areas of Kerala and Tamil Nadu ${ }^{4}$. Similarly, there are active regions rich in granite in France, with a high uranium and thorium content and alumshale, and in Sweeden, with high uranium and radium concentrations which also provide larger doses of radiation. Radionuclides are found naturally in air, water and soil. Natural background radiation is of terrestrial and extra-terrestrial origin [1]. Natural environmental radioactivity and the associated external exposure due to gamma radiation depend primarily on the geographical and geological conditions and appear at different levels of the soils of each region in the world. There are few regions in the world known to be high background radiation areas due to local geology and geo chemical effects that cause enhanced levels of terrestrial radiation [2]. In the high background areas of the country such as Austria, Brazil, China, France, India and Iran the radiation levels were found to be high varying over an order of magnitude depending upon the site-specific terrestrial radioactivity[3]. In India there are quite a few monazite sand bearing placer deposits causing high background radiation along its long coastal line. Ullal in Karnataka, Kalppakkam in Tamil Nadu, coastal parts of Tamil Nadu and Kerala state and south western coast of India are known to be high back ground radiation areas [4]. One of the areas in the south west coast where high radiation level has been reported was from coastal regions of Kanyakumari district, in Tamil Nadu. Beach sand in these areas contains heavy minerals like ilmenite, rutile, zircon, monazite and sillimanite. ${ }^{232} \mathrm{Th}$ and ${ }^{238} \mathrm{U}$ are reported from these regions, caused mainly due to the monazite bearing black sands. Combinations of favorable factors like the hinterland geology, geomorphology, sub-tropical climate and intricate network of drainage aided by wind and coastal processes like waves and currents have influenced these formations [5]. Monazite sands are known to contain thorium with some extent of ${ }^{238} \mathrm{U}$ and ${ }^{40} \mathrm{~K}$. Since the radionuclides are not uniformly distributed the knowledge of their distribution in soil plays an important role in radiation protection and measurement. Also the radioactivity of soils is essential for understanding changes in the natural background [6]. In sense of lives, health and environmental pollution determination of the radioactivity concentration in sands is useful. Therefore an attempt is made in the present investigation to studies on the natural radioactivity content in the beach sands of coastal regions of Kanyakumari district.

\section{Literature Survey}

Menon et al., explains the naturally occurring radionuclides present in soil include ${ }^{228} \mathrm{Ra},{ }^{226} \mathrm{Ra},{ }^{238} \mathrm{U},{ }^{232} \mathrm{Th}$ and ${ }^{40} \mathrm{~K}$. Khan et al., gives the knowledge of their distribution in soil and rocks plays an important role in radiation protection and measurement. Uosif.M and Tahir.A provides the assessment of radiation doses from natural radioactive sources is of particular importance as it is the largest contributor to the external dose of the world population. The world is naturally radioactive and around $90 \%$ of the human radiation exposure arises from natural sources such as cosmic radiation exposure to radon gas and terrestrial radiation. United Nations Scientific Committee on the effects of Atomic Radiation (UNSCEAR),Sources Effects and Risks of Ionizing Radiation Reported to the General Assembly, 


\section{International Journal of Science and Research (IJSR) \\ ISSN (Online): 2319-7064}

Index Copernicus Value (2013): 6.14 | Impact Factor (2014): 5.611

United Nations, New York, that In India, there are quite a few monazite sand bearing placer deposits causing natural high background radiation areas along its long coastal line.

Aswathanarayana.U explains Ilmenite rich beach sand deposits occur in the coastal stretches of Kerala, Tamil Nadu, Andhra Pradesh, Orissa and Maharastra which contain monazite bearing black sands. Several publications are available regarding the beach placers in India. Mir Azam Ali gave a brief account of the placer deposits of the Ratnagiri district, Maharastra. ${ }^{232} \mathrm{Th}$ and ${ }^{238} \mathrm{U}$ are reported from these regions, caused mainly due to the monazite bearing black sands. Sankaran et al., reported ${ }^{238} \mathrm{U}$ and ${ }^{238} \mathrm{Th}$ content of the rocks around this region varied from 1 to 3 ppm with a mean of $2 \mathrm{ppm}$ and from 5 to $15 \mathrm{ppm}$ with a mean of $10 \mathrm{ppm}$ respectively, while the ${ }^{40} \mathrm{~K}$ content varied from 0.2 to $1 \%$. Extensive work has been carried out by various research groups such as Lekshmi et al., Khanna.D et al., Iyengar M.A.R et al., Maniyan C.G. et al., to measure the radioactivity levels and geo-chemical characterization in the soil and sand samples around the beaches at various locations in India.

\section{Materials and Methods}

\subsection{Study Area and Sample collection}

The area under study represents a part of south west coast of Tamil Nadu and is mainly the coastal stretch (Naturally High Background Radiation Area) in Kanyakumari district. The beach sands were collected from five major sites namely Enayam, Midalam, Melmidalam, Thengapattinam and Puthenthurai. Fig.1. represents map of the study area. The samples were collected in a polythene bag and brought to the laboratory.

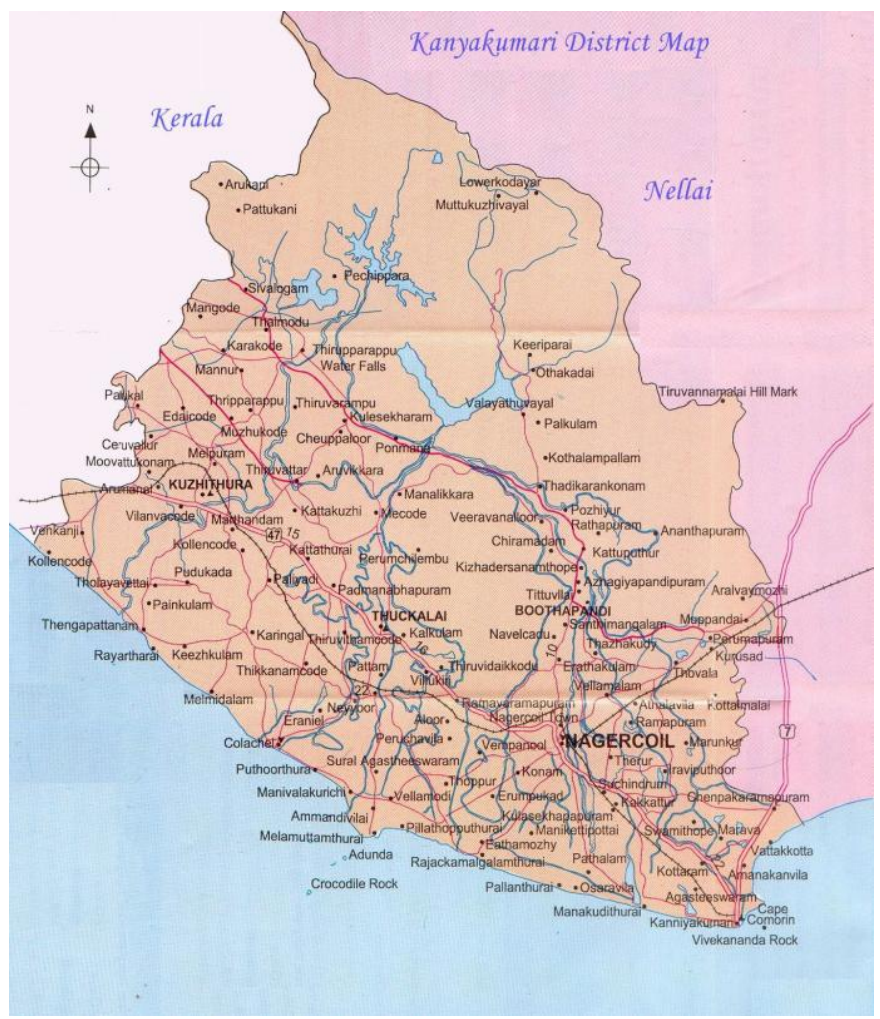

\subsection{Sample processing and activity determination}

Soil samples collected from various beaches were brought to the laboratory. Organic material roots, vegetation pebbles etc., if present were removed and the samples were initially sun dried by spreading them in a tray. Samples were later dried in an oven at $110^{\circ} \mathrm{c}$ for complete removal of moisture for 24 hours. These samples were filled in plastic containers. Sample containers were filled with $300-500 \mathrm{gm}$ of the samples for uniformity and sealed with adhesive tapes to make them air tight depending on the density of the sample. These sample containers were stored for a period of one month before Gamma spectrometric analysis so as allow the establishment of secular equilibrium between ${ }^{226} \mathrm{Ra},{ }^{232} \mathrm{Th}$ and their daughter products. Estimation of ${ }^{226} \mathrm{Ra},{ }^{232 \mathrm{Th}}$ and ${ }^{40} \mathrm{~K}$ in the sand samples were carried out by using high resolution Gamma ray spectrometry comprising a high purity $\mathrm{NaI}(\mathrm{Tl})$ detector(Electronic Enterprises Pvt.Ltd, Mumbai). Samples were counted on a Canberra make vertically oriented $\mathrm{NaI}(\mathrm{Tl})$ having a relative efficiency of $24.8 \%$ and resolution of $1.95 \mathrm{kev}$ for $13.32 \mathrm{kev}$ peak of ${ }^{60} \mathrm{Co}$ [7]. Efficiency calibration of the system is carried out by using secondary standard sources (RGU-1 (400 $\mu \mathrm{g} / \mathrm{g}$ of ${ }^{238} \mathrm{U}$ ) and RGTh-1 $\left(800 \mu \mathrm{g} / \mathrm{g}\right.$ of $\left.{ }^{232} \mathrm{Th}\right)$ procured from IAEA. Estimation of natural radioactivity were carried by measuring the following Gamma energies viz., ${ }^{226} \mathrm{Ra}$ directly through the $186.2 \mathrm{kev}$ and indirectly by measuring the ${ }^{214} \mathrm{Bi}$ (609.3 kev, 1120.2kev and 1764.5kev) and ${ }^{214} \mathrm{~Pb}(351.9 \mathrm{kev}$ photo peaks. ${ }^{232} \mathrm{Th}$ is estimated through ${ }^{228} \mathrm{Ac}(911.2 \mathrm{kev})$ ${ }^{212} \mathrm{~Pb}(238.6 \mathrm{kev})$ and ${ }^{208} \mathrm{Tl}(2614 \mathrm{kev})$ photo peaks, and estimation of ${ }^{40} \mathrm{k}$ through the $1460.8 \mathrm{kev}$ photo peak ${ }^{226} \mathrm{Ra}$ and ${ }^{232} \mathrm{Th}$ were estimated by measuring different daughters that emit clear Gamma peaks of high intensity to confirm the attainment of radioactive secular equilibrium within the samples between ${ }^{226} \mathrm{Ra}$ and its daughters. All the samples were counted for 3000 seconds.

\section{Results and Discussion}

The average radioactivity content in the samples in $\mathrm{Bq} / \mathrm{kg}$ is given in table 1.From the results it is evident that the overall high activity of ${ }_{\mathrm{Ra}}^{226}$ is found in Puthenthurai $(458 \mathrm{~Bq} / \mathrm{kg}$ ) and it is low at Enayam $(269 \mathrm{~Bq} / \mathrm{kg})$. The pattern of variation of ${ }^{40} \mathrm{~K}$ shows that it is low at Enayam (77 Bq/kg) and high at Thengapattinam $(108 \mathrm{~Bq} / \mathrm{kg})$. A high radioactivity content for ${ }^{238} \mathrm{U}$ is estimated at Puthenthurai $(427 \mathrm{~Bq} / \mathrm{kg})$ and a lower content of $(237 \mathrm{~Bq} / \mathrm{kg})$ is found at Enayam. The activity variation for ${ }^{232} \mathrm{Th}$ shows that Puthenthurai has the highest radioactivity concentration $(3250 \mathrm{~Bq} / \mathrm{kg})$ and Enayam has the lowest concentration of (2302 Bq/kg).

Table 1: Average radioactivity in $\mathrm{Bq} / \mathrm{kg}$

\begin{tabular}{|c|c|c|c|c|}
\hline \multirow{2}{*}{ Sampling sites } & \multicolumn{4}{|c|}{ Average activity in $\mathrm{Bq} / \mathrm{kg}$} \\
\cline { 2 - 5 } & ${ }^{226} \mathrm{Ra}$ & ${ }^{228} \mathrm{Ra}$ & ${ }^{40} \mathrm{~K}$ & ${ }^{232} \mathrm{Th}$ \\
\hline Enayam & 269 & 237 & 77 & 2302 \\
\hline Midalam & 320 & 289 & 87 & 2836 \\
\hline Melmidalam & 362 & 351 & 83 & 2919 \\
\hline Thengapattinam & 359 & 324 & 108 & 2750 \\
\hline Puthenthurai & 458 & 427 & 68 & 1189 \\
\hline
\end{tabular}

Figure 1: Map of the Sampling stations 


\section{International Journal of Science and Research (IJSR) \\ ISSN (Online): 2319-7064}

Index Copernicus Value (2013): 6.14 | Impact Factor (2014): 5.611

\section{Absorbed dose}

The absorbed dose rate (D) [8] due to gamma radiations in air at $1 \mathrm{~m}$ above ground level for the uniform distribution of naturally occurring nuclides was calculated using equation (1):

$$
\mathrm{D}=0.462 \mathrm{C}_{\mathrm{Ra}}+0.604 \mathrm{C}_{\mathrm{Th}}+0.0042 \mathrm{C}_{\mathrm{k}}
$$

Where $\mathrm{D}$ is the absorbed dose rate in $\mathrm{nGyh}^{-1}$ and $\mathrm{C}_{\mathrm{Ra}}, \mathrm{C}_{\mathrm{Th}}$ and $\mathrm{C}_{\mathrm{k}}$ are the activity concentrations of ${ }^{226} \mathrm{Ra},{ }^{232} \mathrm{Th}$ and ${ }^{40} \mathrm{~K}$ in the soil samples in $\mathrm{Bq} / \mathrm{Kg}$.

\subsection{Annual Effective Dose}

To estimate the annual effective dose, two important factors must be taken into account (i) the conversion coefficient from the absorbed dose in air to the effective dose and (ii) the indoor occupancy factor. The former gives the equivalent dose in $\mathrm{Svy}^{-1}$ from absorbed dose in air $\mathrm{Gyh}^{-1}$, while the latter gives the fraction of the time the individual is exposed to outdoor radiation. The first factor has been recommended by UNSCEAR, 2000 as $0.7 \mathrm{SvGy}^{-1}$ and the second factor as 0.2 , which suggests that there is variation from absorbed dose in air to effective dose received by adults. The annual effective dose is calculated, taking into consideration that people in India, on an average, spend nearly $20 \%$ of their time outdoors. To estimate the annual effective dose rate, their conversion coefficient from absorbed dose in air to effective dose $\left(0.7 \mathrm{SvGy}^{-1}\right)$ and outdoor occupancy factor of (0.2) proposed by UNSCEAR, 2000 were used. The annual effective dose rate [9] in units of $\mathrm{mSvy}^{-1}$ was calculated by using equation (2):

Annual effective dose $=\mathrm{D} \times(24 \times 365) \times 0.7 \times 0.2 \times 10^{-6}$ $\mathrm{mSv}$.

Table 2: Absorbed dose and Annual Effective Dose in the study area

\begin{tabular}{|c|c|c|}
\hline Sampling sites & Absorbed Dose $\left(n G y h^{-1}\right)$ & $\begin{array}{c}\text { Annual Effective } \\
\text { Dose }(\mathrm{mSv})\end{array}$ \\
\hline Enayam & 1517.92 & 1.86 \\
\hline Midalam & 1864.43 & 2.28 \\
\hline Melmidalam & 1933.80 & 2.37 \\
\hline Thengapattinam & 1831.39 & 2.24 \\
\hline Puthenthurai & 2178.75 & 2.67 \\
\hline
\end{tabular}

Table 2. gives the absorbed dose and the annual effective dose from soil. The absorbed dose ranges from 1517.92 to $2178.75 \mathrm{nGyh}^{-1}$. To estimate the annual effective dose, the indoor occupancy factor and the conversion coefficient from the absorbed dose in air to effective dose must be taken into account. The annual effective dose ranges from $1.86 \mathrm{mSv}$ to $2.67 \mathrm{mSv}$.

\section{Conclusion}

Radiological assessment for the soil samples collected from the study area indicates that the concentration of radionuclides ranges from 269 to $458 \mathrm{~Bq} / \mathrm{Kg}$ for ${ }^{226} \mathrm{Ra}, 237$ to $427 \mathrm{~Bq} / \mathrm{Kg}$ for ${ }^{228} \mathrm{Ra}, 2302$ to $3250 \mathrm{~Bq} / \mathrm{Kg}$ for ${ }^{232} \mathrm{Th}$ and 77 to $108 \mathrm{~Bq} / \mathrm{Kg}$ for ${ }^{40} \mathrm{~K}$. The absorbed dose in air ranges from $1517.92 \mathrm{nGy} / \mathrm{h}$ to $2178.75 \mathrm{nGy} / \mathrm{h}$ and the Annual effective dose lie between $1.86 \mathrm{mSv}$ to $2.67 \mathrm{mSv}$. This enhanced level of radioactivity is due to monazite bearing black sand which is an orthophosphate of thorium, uranium and rare earths, present with a concentration varying from 0.3 to $5 \%$ in the soils of this area. The highest level of dose $2.67 \mathrm{mSv}$ is estimated at Enayam this is due to the fact that beach sands in these areas contain heavy minerals like ilmenite, rutile, garnet, zircon, monazite, magnetite, sillmenite etc., Combination of favorable factors like the hinter land geology, coastal geomorphology, sub-tropical climate and intricate network of drainage aided by wind and coastal processes like waves and currents have influenced this formation.

\section{Future Scope}

The dose due to drinking water and air can be further estimated and from this the total dose due to air, water and soil to general public in the area can be determined

\section{References}

[1] UNSCEAR, 2000. United Nations Scientific Committee on the effects of Atomic Radiation (UNSCEAR),Sources Effects and Risks of Ionizing Radiation Report to the General Assembly, United Nations, New York, USA.

[2] Iyengar, M.A.R., and Kannan, V., 1994. Natural Radiation aspects in the high background areas at Kalpakkam, Proc. $3^{\text {rd }}$ National Symposium on Environment, Thiruvananthapuram, March, 1994, pp. 48-55.Lakshmi, K.S., Selvasekarpandian, S., Kanna,D. and Meenakshisundaram, V., 2005. Primordial radionuclides concentrations in the beach sands of east coast region of Tamil Nadu, India. International Congress Series, vol.1276, 323-324.

[3] Mohanty, A.K., Sengupta, D., Das, S.K., Saha, S.K., and Vijayan, K.V.,2004. Natural radioactivity and radiation exposure in the high background area at Chhatrapur beach placer deposit of Orissa, India. Journal of Environmental Radioactivity, 75, 15-33.

[4] Ramasamy, V.,Senthil,S.,Meenakshisundaram and Gajendran, V., 2009. Measurement of natural radioactivity in beach sediments collected from north east coast of Tamil Nadu, India. Research Journal of Applied Scie., Eng. And Technology, 1(2) 54-58.

[5] El-Arabi, A.M., 2007. 226Ra, 232Th and 40K concentrations in igneous rocks from eastern desert, Egypt and its radiological implications. Radiation Measurements, 42, 94-100.A.A Shanbhag,S.J.Sartandel,T.V.Ramachandran and V.D Puranik 2005.Natural Radioactivity content in beach sands of Ratnagiri coast Maharashtra, Environmental Geo chemistry,vol.8,no.1\&2, PP.304-308.

[6] Veiga, R., Sanches, N., Anjos, R.M., Macario, K., Bastos, J., Iguatemy, M., Aguiar, J.G., Santos, A.M.A., Mosquera, B., Carvalho, C., Baptista Filho, M. and Umisedo, N.K., 2006. Measurement of natural radioactivity in Brazilian beach sands. Radiation Measurements, 41, 189-196.

[7] Kerur, B.R., Anil Kumar, S. 2012 Dose due to Radioactive nuclides in Soil of Karnataka. Proceedings of NSRP-19, Mamallapuram, Tamil Nadu, India. PP.444-446.

\section{Volume 4 Issue 12, December 2015}




\section{International Journal of Science and Research (IJSR) \\ ISSN (Online): 2319-7064 \\ Index Copernicus Value (2013): 6.14 | Impact Factor (2014): 5.611}

[8] Menon, M.R., Mishra, U.C., Lalit, B.Y., Shukla, V.K., Ramachandran, T.V., 1982. Uranium, thorium and potassium in Indian rocks and ores. Proceedings of the Indian Academy of Sciences(Eaerth Planetary Sciences) 91, 127-136.Khan, H.M., Khan,K., Atta, M.A., Jan, F., 1994. Measurement of gamma activity of soil samples of Charssada district of Psakistan. Journal of Chemical Society of Pakistan, 16, 183-188.

[9] Uosif, M. and Tahir, A., 2008. Radiological assessment of abu tarpur phosphate western desert Egypt, Radiation Protection Dosimetry, 7(1-4), 87-89.

[10] Overstreet, W. C. (1967) The geologic occurrence of Monazite.U.S. Geological survey professional paper, 530.

[11] Mir Azam Ali, Krishnan, S. and Banerjee, D.C., 2001.Beach and heavy mineral sand investigations and deposits in India- An overview, special issue on beach and inland heavy mineral sand deposits of India. Exploration and Research for Atomic minerals, 13, pp.1-21.

[12] Aswathanarayana, U., 1964. Origin of the heavy mineral beach sand deposits of the south west coast of India. In: Eds. A.P. Subramanian and S. BalakrishnaAdvancing Frontiers in Geology and Geophysics, Indian Geophysical union, Hyderabad. Pp.481-489.

[13] Sankaran, A.V., Jayaswal, B., Nambi, K.S.V. and Sunta, C.M., 1988. $U$, Th and $K$ distributions inferred from regional geology and the terrestrial radiation profiles in India. BARC, Bombay, pp.1-104.

[14] Paul AC, Pillai PMB, Haridasan PP, Sujatha Radhakrishnan and Krishnamony S. Population exposure to airborne thorium at the high natural radiation areas in India, Journal of Environmental Radioactivity, 40 (3), 251-259, 1998.

[15]Lakshmi, K.S., Selvasekarpandian, S., Kanna,D. and Meenakshisundaram, V., 2005. Primordial radionuclides concentrations in the beach sands of east coast region of TamilNadu, India. International Congress Series, vol.1276, 323-324.

[16] Khanna, D., Malathi, J., Brahmanandhan, G.M. and Selvasekarapandian, S., 2004. Measurement of activity concentrations of $40 \mathrm{~K}, 238 \mathrm{U}$ and $232 \mathrm{Th}$ in soil samples of Agastheeswaram Taluk, Kanyakumari District, India., paper presented in the Sixth International Conference on High Level Radiation Areas, Japan. September 5-9, 2004.

[17] Iyengar, M.A.R., and Kannan, V., 1994. Natural Radiation aspects in the high background areas at Kalpakkam, Proc. $3^{\text {rd }}$ National Symposium on Environment, Thiruvananthapuram, March, 1994, pp. 48-55.

\section{Author Profile}

Mrs. Sarojini has been working as Assistant Professor in Physics at Lekshmipuram College of Arts \& Science, Neyyoor for the past 11 years and doing Research in Radiation Physics. The author is a life member in Indian Science Congress, Indian Society for Radiation Physics, Indian Society for Radiation Biology and in Kanyakumari Academy of Arts \& Science. She has also published 8 International papers in the field of Radiation Physics.She received her Ph.D degree in the year 2013.
Dr. Cithambarathanu has been working as Associate Professor in S.T.Hindu College, Nagercoil for the past 26 years. He received his Ph.D degree in the year 2003 from M.S.University, Tirunelveli. His major research interests are in Molecular Spectroscopy\& Environmental Physics. He has successfully completed his research project entitled "A Study of Surface Ozone variation in Nagercoil, Southern Tamil Nadu" funded by University Grants Commission. He has published more than 50 papers and conducted four national level seminars funded by BARC, NPCIL, IREL and UGC. Sp 